\title{
Environmental Sustainability In The Thai Hotel Industry
}

\author{
Jirawat Anuwichanont, Ph.D., Suan Dusit Rajabhat University, Thailand \\ Asst. Prof. Dr. Panisa Mechinda, Ph.D., Rajamangala University of Technology, Thailand \\ Associate Professor Sirivan Serirat, Graduate School, Rajabhat Suan Dusit University, Thailand \\ Aurathai Lertwannawit, Ph.D., Rajabhat Suan Dusit University, Thailand \\ Nongluck Popaijit, Suan Dusit Rajabhat University, Thailand
}

\begin{abstract}
Nowadays, the growing concern of environmental sustainability does not only influence consumers' demand but also how companies run their own business. Consumers are more conscious about the environment and demanding environmental friendly products and services. Consequently, the tourism industry currently faces increasing demands from consumers to achieve levels of environmental responsiveness. Thus, companies strive to implement environmentally friendly and socially responsible practices to gain competitive advantage, while still maintaining commercial success. Moreover, empirical evidence indicated that companies' increased environmental support results in the development of customer trust and commitment as well as higher profitability. Thus, this study attempts to investigate the antecedents of loyalty in the hotel industry by examining the impacts of attitude toward the hotel's environmental concern, subjective norms, perceived value and destination competitiveness on customers' future intentions. Also, the comparative examination of these relationships between high and low environmental concern groups was included. Results revealed that perceived value is, followed by destination competiveness, the most powerful predictor of future intentions in both high and low environmental concern groups. In addition, attitude towards the hotel's environmental concern significantly influenced future intentions solely in high environmental concern group. Contrary to our expectation, subjective norms exerted no significant effect on future intentions in both groups.
\end{abstract}

Keywords: Environmental Concern; Perceived Value; Destination Competitiveness; Future Intentions

\section{INTRODUCTION}

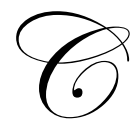

oncern about environmental sustainability has dramatically increased and influenced both the way consumers behave and the way the companies run business (Bergin-Seers and Mair 2009). The development of tourism industry has both positive and negative effects (Holjevac 2003; Archer and Cooper 1994). Positive effects are in terms of economic development and growth whereas negative effects are deterioration of natural resources. Therefore, if the destination is appropriately managed, the resources that appealing to tourists are maintained over time, the destination can be differentiated and its competitiveness can be increased and sustained (Hu and Wall 2005; Mihalic 2000). As Enrique and colleagues (2007) suggested that hotels should adopt and implement a sustainable tourism policy to preserve their destination and consequently their competitiveness. Consistently, companies holding environmental concerns theoretically achieve a competitive advantage over its competition since these shared values contribute significantly to the development of customer trust and commitment (Dwyer et al., 1987). Moreover, the positive association between increased environmental support by businesses and increased profit was empirically supported (Bonifant et al., 1995; Miles \& Covin, 2000). In this study, we attempt to compare the relative effects of the following variables such as attitude toward the hotel's environmental concern, subjective norms of tourists, perceived value, destination competitiveness (in terms of natural resources) on future intentions to stay with the hotel. Additionally, this model is compared between two groups of tourists: those with high concern for environment and those with low concern for environment. 


\section{RESEARCH OBJECTIVES}

The objectives of this research are as follows:

- $\quad$ to examine the effects of attitude towards the hotel's environmental concern, subjective norms, perceived value, destination competitiveness on future intentions

- $\quad$ to examine the aforementioned relationships between high and low environmental concern groups

\section{LITERATURE REVIEW AND HYPOTHESES DEVELOPMENT}

\section{Future Intentions}

According to Zeithaml et al., (1996), behvaioral intention of customer represents their willingness to repatronizing the company. Thus, it is an important concept, particularly in competitive market like tourism. Chauduri and Holbrook (2001) argued that behavioral intention can be linked to market share. Moreover, Zeithaml, Berry and Parasuraman (1996) described the lists of behavioral intentions such as loyalty, switching intentions and willingness to pay more. Empirically, Ozdemir and Hewett (2010) have conceptualized behavioral intention as a higher-order construct consisting of (1) positive word of mouth (Boulding et al., 1993), (2) willingness to recommend (PBZ 1991) and (3) intention to continue buying from a particular service provider (Bowen and Shoemaker 1998). This study conceptualized behavioral intention as intention to repatronize the service provider (hotel) or repurchase intention (Bolton et al.2000).

\section{Environmental Concern}

From a theoretical perspective, environmental concern refers to "individual's orientation toward the environment" (Kim and Choi 2005). It has been viewed as uni-dimensional construct ranging from no concern at all to high concern (Milfont and Duckitt 2004). It was found to predict environmentally conscious behavior such as recycling behavior (Simmons and Widmar1990), green buying behavior (Chan 1996). However, the empirical research has shown that the relationship between environmental concern and green buying is low to moderate (Hines et al., 1987).

\section{Attitude toward the hotel's environmental concern}

Earlier research provides support for the notion that attitude influences behavioral intention (Ajzen and Fishbein 1980) and this influence has been supported by many empirical evidence (e.g. Fitzmaurice 2005; Pavlou and Fygenson 2006; Thorbjornsen et el., 2007). Research has shown that hotel's environmental concern can enhance destination quality, which in turn increase the value of product (Mathieson and Wall 1982), the number of tourists and the number of repeated visits (Hu and Wall 2005) as well as more revenues (Kirk 1998). As a result, in this study, attitude toward the hotel's environmental concern is measured and posited that

$H_{1}$ : Attitude toward hotel's environmental concern will exert a direct influence on tourists' future intentions.

\section{Subjective Norm}

Based on The Theory of Planned Behavior (TPB) (Ajzen 1991), which is an extension of the Theory of Reasoned Action (Azjen and Fishbein 1970), subjective norm is one of ingredients of the model that predicts consumer behavior. According to TPB, behavioral intentions are partly (not fully) determined by a weighted combination of attitude and subjective norm. Since behavioral intentions changed over time, TPB postulated that intentions at any point in time are determined by three important factors: (1) attitude toward the behavior, (2) subjective norm governing the behavior, (3) time and chance which is 'perceived behavioral control' (Wang et al.2007). Fishbein and Ajzen (1975) suggested that the relative importance of these factors may depend on demographics variables and personality variables. 
Subjective norm is based on normative beliefs. It is belief about what other people (who are very important to the respondent) think the respondent should do and the motivation of the respondent to comply with the views of the others (Lodorfos and Dennis 2008). Many researchers concluded that the influence of subjective norm on behavior is context dependent (Hubner and Kaiser 2006; Legris, Ingham and Collerette 2003). However, in this study, we want to explore the impact of subjective norm on the future intention. As a result, we hypothesize that

$\mathrm{H}_{2}$ : Subjective norm will exert a direct influence on tourists' future intentions.

\section{Perceived Value}

Empirical findings extensively support perceived value as a critical tool for gaining competitive advantage (Parasuraman 1997). It is defined as "the total benefits that customers receive from consumption relative to the total costs that customers have to pay in order to get those benefits (which include the price paid plus other costs associated with the purchase (Woodruff 1997). Empirical researches have shown that perceived value is a key determinant of repurchase intention (Cronin et al., 2000; Petrick 2004). Research has suggested that perceived value may be a better predictor of repurchase intentions, than either satisfaction or quality (Cronin, Brady and Hult 2000). Based on equity theory (Oliver and DeSarbo, 1988), customers are inclined to feel equitably treated if they perceive that the ratio of their outcome to inputs is comparable to the ratio of outcome of inputs experienced by the company. Consistently, perceived value was found to be good predictors of entertainment vacationers' intention to revisit a destination (Petrick, Morais and Norman 2001). Bolton and Drew (1991) have shown that future intentions are determined in part by perceived value. In making the decision to return to the service provider, customers are likely to consider whether or not they received value for money (Zeithaml 1988). As a result, the next hypotheses are formulated as follows:

\section{$H_{3}$ : Perceived value towards hotels will exert a direct influence on tourists' future intentions}

\section{Destination competitiveness}

Destination competitiveness is defined in this study as the destination's ability to deliver goods and services that excels better than other destinations (Dwyer and Kim, 2003). There are many variables linking to the concept of destination competitiveness. Based on the framework developed by Dwyer and Kim (2003), natural resources or endowed resources (Dunn and Iso-Ahola, 1991) are considered as core resources which act as primary motivation for tourists (Crouch and Ritchie, 1999). As a consequence, they can influence the attractiveness of destination, thereby intention to visit. They also influence tourist experiences and perceived value of the trip (Murphy et al., 2000). Thus, we hypothesize that

\section{$H_{4}$ : Destination competitiveness (natural resources) will exert a direct influence on tourists' future intention.}

\section{RESEARCH METHODOLOGY}

Target populations are Thai tourists who have experiences staying in hotels in Koh Samet. Derived from indefinite population formula for determining sample size, the calculated sample size for this study is 400 . The list of hotels in Koh Samet was prepared, including 30 hotels. The quota sampling method was employed to collect data from qualified respondents. The criterion of selecting respondents is based on quotas by recruiting 13-14 respondents per hotel from the predetermined list of 30 hotels. The first draft of the questionnaire was subjected to pretesting with total respondents of 40 . The reliability coefficients of the measurement scales from the pretest demonstrated high internal consistency with reliability coefficients exceeding the threshold level of 0.70 (Nunnally, 1978).

\section{MEASURES}

Twelve measures are adapted to measure attitudes toward the hotel's environmental concern. This twelve -item scale asked questions about the consumers' attitudes towards hotels' environmental concern. Subjective norms was operationalized on the basis of six items developed by Ajzen (2006) and Francis et al. (2004). Similarly, perceived value was measured using a four-item scale adapted from previous studies by Parasuraman (1997). The 
scale for measuring destination competitiveness was adapted from Dwyer and Kim (2003). With regards to future intentions, the four-item scale developed by Pritchard et al. (1999) was employed in this study. The measure of environmental concern was adapted from the study of Finisterral \& Mario Linos (1980). All measurement scale demonstrated substantial internal consistency with high reliability estimates in the previous study.

All of the items were measured by a 7 -point Likert scale $(1=$ strongly disagree and $7=$ strong agree $)$. The original English instrument was translated into Thai and then back-translated into English in order to permit a comparison of meaning of the questions. The final self-administered questionnaires were then given to respondents to complete concerning their attitudes towards a focal hotel.

\section{RESULTS}

\section{Respondent profile}

Total number of valid questionnaires obtained was 400. The split-group analysis procedure (high versus low on the environmental concern variable) (Osterhus, 1997) was conducted to examine the differences between the high and low environmental concern groups from the total sample of 400 respondents. Then the total sample was divided into two groups on the basis of the degree of environmental concern by using high versus low median splits on the environmental concern variables. As a result, the high environmental concern group consists of 218 individuals whereas the low environmental concern group consists of 149 individuals.

Table 1: Respondent Profile of Tourists

\begin{tabular}{|c|c|c|c|c|}
\hline \multirow[t]{2}{*}{ Demographic } & \multicolumn{2}{|c|}{$\begin{array}{c}\text { High environmental concern } \\
\text { group }(n=218)\end{array}$} & \multicolumn{2}{|c|}{$\begin{array}{l}\text { Low environmental concern } \\
\text { group }(n=149)\end{array}$} \\
\hline & Frequency & $\%$ & Frequency & $\%$ \\
\hline \multicolumn{5}{|l|}{ Gender } \\
\hline - Male & 107 & 49.10 & 79 & 53.00 \\
\hline - Female & 111 & 50.90 & 70 & 47.00 \\
\hline \multicolumn{5}{|l|}{ Age } \\
\hline - Less than 25 Years & 77 & 35.30 & 75 & 50.30 \\
\hline - 25-34 Years & 123 & 56.40 & 62 & 41.60 \\
\hline - 35 Years and over & 18 & 8.30 & 12 & 8.10 \\
\hline \multicolumn{5}{|l|}{ Marital status } \\
\hline - Single & 180 & 82.60 & 128 & 85.90 \\
\hline - Married/Living together & 38 & 17.40 & 21 & 14.10 \\
\hline \multicolumn{5}{|l|}{ Level of Education } \\
\hline - Less than Bachelor Degree & 28 & 12.80 & 16 & 10.70 \\
\hline - Bachelor Degree & 162 & 74.30 & 106 & 71.10 \\
\hline - Higher than Bachelor Degree & 28 & 12.80 & 27 & 18.10 \\
\hline \multicolumn{5}{|l|}{ Occupation } \\
\hline - Professionals & 11 & 5.00 & 8 & 5.40 \\
\hline - Administrative/Managerial & 13 & 6.00 & 11 & 7.40 \\
\hline - Commercial & 27 & 12.60 & 28 & 18.80 \\
\hline - Government/State Enterprise & 47 & 21.60 & 16 & 10.70 \\
\hline - Retired/Unemployed/Housewives & 10 & 4.60 & 3 & 2.00 \\
\hline - Students & 55 & 25.20 & 52 & 34.90 \\
\hline - Entrepreneurs & 19 & 8.70 & 7 & 4.70 \\
\hline - Others & 36 & 16.50 & 24 & 16.10 \\
\hline \multicolumn{5}{|l|}{ Monthly Household Income } \\
\hline - Less than 450 US\$. & 58 & 26.60 & 45 & 30.20 \\
\hline - 450-900 US\$. & 71 & 32.60 & 45 & 30.20 \\
\hline - 901-1,500 US\$. & 40 & 18.30 & 22 & 14.80 \\
\hline - 1,501-1,950 US\$. & 10 & 4.60 & 19 & 12.80 \\
\hline - 1,951-2,400 US\$. & 10 & 4.60 & 7 & 4.70 \\
\hline - 2,401US\$. and over. & 29 & 13.30 & 11 & 7.40 \\
\hline Total & 218 & 100 & 149 & 100 \\
\hline
\end{tabular}


Regarding the high environmental concern group, it can be indicated that there is almost equal split in the gender of respondent $(50.90 \%$ are female; $49.10 \%$ are male). $56.40 \%$ of them are $25-34$ years old. The majority of them are single $(82.60 \%)$ and hold at least a bachelor's degree $(74.30 \%)$. Most of them are students $(25.20 \%)$ and have an income level between 450-900 US\$ or 15,000-29,999 Baht (32.60\%).

In terms of the low environmental concern group, 53\% of them are female, 50.3\% of them are aged less than 25 years old. The majority of them are single (85.90\%) and have bachelor degree (71.10\%). Their income is less than 450 US\$ (30.20\%) and 450-900 US\$. (30.20\%). Most of them are students $(34.90 \%)$. The details of respondent profile are shown in Table 1.

\section{Scale purification}

The preliminary analysis revealed that the measurement scales of all constructs had acceptable internal consistency, which was evidenced by high Cronbach's alpha ranging from 0.87 - 0.96 which exceeded the threshold value of 0.70 (Nunnally, 1978). In addition, exploratory factor analysis (EFA) using principal component analysis with varimax rotation was carried out to purify the measurement scales and to examine the dimensionality of the items. The findings revealed that only one factor was extracted as expected, which explained approximately 65- 83 percent of the total variance as summarized in Table 2. The findings indicated that all constructs satisfied the criteria of unidimensionality and reliability.

Table 2: Variance Explained and Reliability Results

\begin{tabular}{lcccc}
\hline \multicolumn{1}{c}{ Construct } & \multicolumn{1}{c}{$\begin{array}{c}\text { No. of } \\
\text { factors }\end{array}$} & Variance explained & Eigenvalue & $\begin{array}{c}\text { Reliability } \\
\text { coefficient }\end{array}$ \\
\hline $\begin{array}{l}\text { Attitude toward the hotel's } \\
\text { environmental concern }\end{array}$ & 1 & $68.79 \%$ & 8.25 & 0.96 \\
\hline Subjective norms & 1 & $83.44 \%$ & 5.00 & 0.96 \\
\hline Perceived value & 1 & $80.57 \%$ & 3.22 & 0.92 \\
\hline Destination competiveness & 1 & $77.10 \%$ & 3.08 & 0.90 \\
\hline Future intentions & 1 & $80.46 \%$ & 3.22 & 0.92 \\
\hline Environmental concern & 1 & $65.42 \%$ & 3.27 & 0.87 \\
\hline
\end{tabular}

Before estimating the hypothesized conceptual model, it is highly recommended to identify the correlation problem or multicollinearity among independent variables (Hair et al., 1998; Tabachnick and Fidell, 2001). Theoretically, the correlation values between constructs exceeding 0.90 can be indicative of multicollinearity (Hair et al., 1995).The findings reveal that the correlation coefficients between the predictor variables are less than 0.90, indicating little or no problem of multicolinearity. Table 3 reports the results of the correlation analysis for the variables hypothesized to be related to future intentions, along with means and standard deviation of each variable.

Table 3: Means, Standard Deviations and Intercorrelations among Constructs

\begin{tabular}{|c|c|c|c|c|c|c|c|}
\hline & Means & SD. & Y1 & $\mathbf{X 1}$ & $\mathbf{X} 2$ & $\mathbf{X 3}$ & $\mathbf{X 4}$ \\
\hline Future Intentions (Y1) & 4.75 & 1.434 & 1.00 & & & & \\
\hline Attitude toward the hotel's environment concern (X1) & 4.27 & 1.238 & $.429 * *$ & 1.00 & & & \\
\hline Subjective norms (X2) & 5.57 & 1.296 & $.182 * *$ & $.233 * *$ & 1.00 & & \\
\hline Perceived value (X3) & 4.49 & 1.255 & $.513 * *$ & $.435 * *$ & $.104 *$ & 1.00 & \\
\hline Destination competiveness (X4) & 4.98 & 1.110 & $.360 * *$ & $.325 * *$ & $.264 * *$ & $.311 * *$ & 1.00 \\
\hline
\end{tabular}

Note: $* *$ Correlation is significant at the 0.01 level (2-tailed), **Significant at $\mathrm{p}<.01$

*Correlation is significant at the 0.05 level (2-tailed), *Significant at $\mathrm{p}<.05$

\section{Hypotheses Testing}

The relationships hypothesized in $\mathrm{H}_{1}$ to $\mathrm{H}_{4}$ were tested by using multiple regression analysis with tourists' future intentions as the dependent variable. Hypotheses $\mathrm{H}_{1}$ predicted a positive relationship between attitude toward 
the hotel's environment concern and future intentions. The multiple regression results revealed that attitude toward the hotel's environment concern, as hypothesized, was found to significantly influence future intentions only in the high environmental concern group $(\beta=.234, \mathrm{p}<0.01)$. In contrast, $\mathrm{H}_{1}$ was not supported in the low environmental concern group $(\beta=.109, \mathrm{p}>0.05)$ due to the statistically insignificant coefficient.

Hypotheses $\mathrm{H}_{2}$ stated that subjective norms will be positively associated with future intentions. The regression results show that the beta coefficients of both high and low environmental concern groups were statistically insignificant (high group: $\beta=.025, p>0.05$, low group: $\beta=.108, p>0.05$ ). It should be noted that counter to the author's predictions, the relationship between subjective norms and future intentions was statistically insignificant. Hence, no support was found for the hypotheses $\mathrm{H}_{2}$ in both groups.

Hypotheses $\mathrm{H}_{3}$ predicted a positive relationship between perceived value and future intentions. The results were consistent with this prediction as evidenced by positive and significant path coefficients towards future intentions in the high environmental concern group $(\beta=.387, \mathrm{p}<0.01)$ and the low environmental concern group $(\beta$ $=.381, \mathrm{p}<0.01)$. The positive association between perceived value and future intentions was consistent with previous studies of Cronin, Brady and Hult (2000) and Oh (2000) wherein perceived value was found to be the indicator of repurchase intentions. Thus, this result complemented past research and was supportive of $\mathrm{H}_{3}$.

Hypotheses $\mathrm{H}_{4}$ proposed a positive relationship between destination competiveness and future intentions. The finding revealed that destination competiveness was found to significantly affect future intentions in both high $(\beta=.137, \mathrm{p}<0.05)$ and low environmental concern group $(\beta=.170, \mathrm{p}<0.05)$, both at the significance level of 0.05 , providing support for $\mathrm{H}_{4}$. Results of the hypotheses testing of both groups are demonstrated in Table 4 .

Table 4: Summary of Hypotheses Testing Results

\begin{tabular}{|c|c|c|c|c|c|c|c|c|}
\hline \multirow[b]{2}{*}{ Hypotheses } & \multicolumn{4}{|c|}{$\begin{array}{l}\text { High Environmental } \\
\text { Concern Group }\end{array}$} & \multicolumn{4}{|c|}{$\begin{array}{l}\text { Low Environmental } \\
\text { Concern Group }\end{array}$} \\
\hline & $\begin{array}{l}\text { Standardized } \\
\text { Coefficients } \\
\text { (Beta) }\end{array}$ & $\mathbf{t}$ & Sig. & Results & $\begin{array}{l}\text { Standardized } \\
\text { Coefficients } \\
\text { (Beta) }\end{array}$ & $\mathbf{t}$ & Sig. & Results \\
\hline $\begin{array}{l}\mathrm{H}_{1} \text { : Attitude toward the hotel's } \\
\text { environment concern } \\
\rightarrow \quad \text { Future intentions }\end{array}$ & $.234 * *$ & 3.635 & .000 & Supported & .109 & 1.390 & .167 & $\begin{array}{c}\text { Not } \\
\text { supported }\end{array}$ \\
\hline 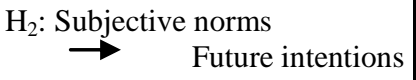 & .025 & 0.439 & .661 & $\begin{array}{c}\text { Not } \\
\text { supported }\end{array}$ & .108 & 1.408 & .161 & $\begin{array}{c}\text { Not } \\
\text { supported }\end{array}$ \\
\hline $\mathrm{H}_{3}: \stackrel{\text { Perceived value }}{\rightarrow} \quad$ Future intentions & $.387 * *$ & 6.169 & .000 & Supported & $.381 * *$ & 4.745 & .000 & Supported \\
\hline $\begin{array}{c}\mathrm{H}_{4}: \text { Destination competiveness } \\
\rightarrow \quad \text { Future intentions }\end{array}$ & $.137 *$ & 2.319 & .021 & Supported & $.170 *$ & 2.131 & .035 & Supported \\
\hline $\mathrm{R}^{2}$ & \multicolumn{4}{|c|}{.346} & \multicolumn{4}{|c|}{.329} \\
\hline Adj. $R^{2}$ & \multicolumn{4}{|c|}{.334} & \multicolumn{4}{|c|}{.311} \\
\hline F-value & \multicolumn{4}{|c|}{28.16} & \multicolumn{4}{|c|}{17.67} \\
\hline
\end{tabular}

Notes: Dependent Variable: Tourists' Future Intentions

$* \mathrm{p}<0.05 ; * * \mathrm{p}<0.01$

In summary, the most powerful predictor of future intentions in the high environmental concern group was perceived value $(\beta=.387)$, followed by attitude towards the hotel's environmental concern $(\beta=.234)$ and destination competiveness $(\beta=.137)$ respectively. Contrary to our expectation, subjective norms insignificantly influenced future intentions. For the low environmental concern tourists, the most powerful predictor of future 
intentions was perceived value $(\beta=.381)$, followed by destination competiveness $(\beta=.170)$. In addition, the attitude towards the hotel's environmental concern and subjective norms exerted no significant effect on future intentions.

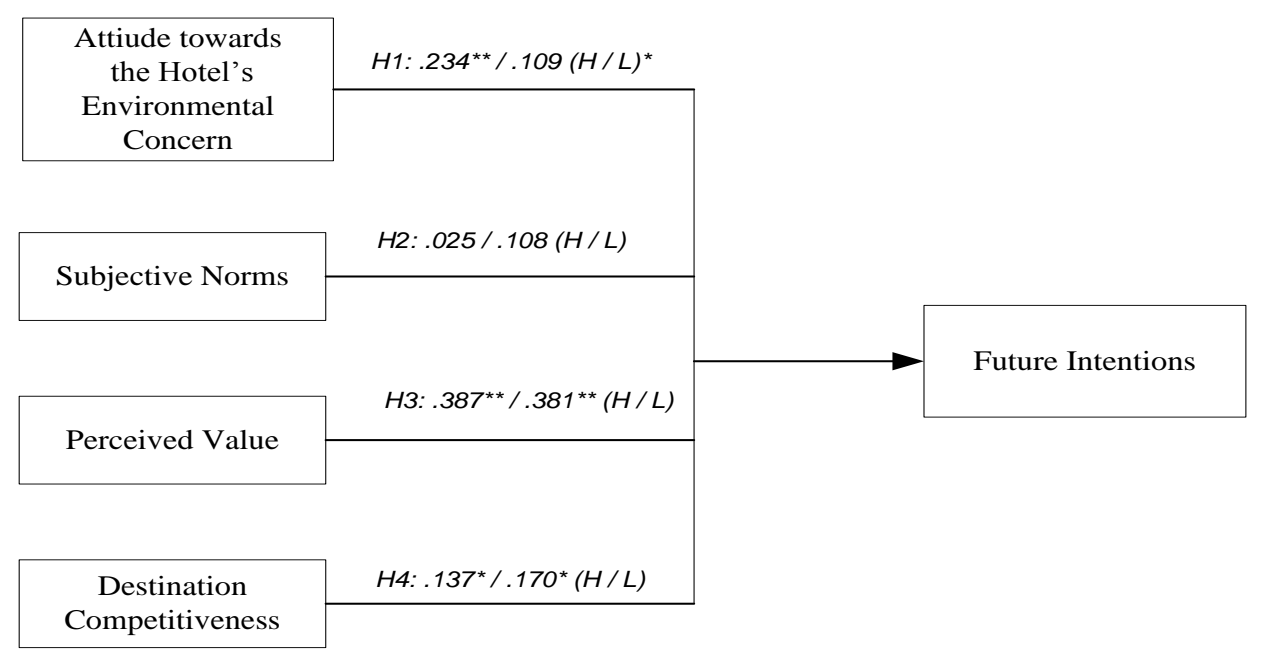

Figure 1: Conceptual Model

*(H/L): ( High / Low environmental concern group)

\section{DISCUSSION AND CONCLUSION}

As hypothesized, the empirical results indicate that service loyalty, in terms of future intentions, is determined by the extent of customers' attitude towards the hotel's environmental concern, but solely in the high environmental group. This finding is consistent with the preceding literature review (e.g. Hu and Wall 2005) supporting the notion that attitude is regarded as essential precursors of behavior. Moreover, this finding is consistent with the findings of Baldinger and Rubinson (1996) that customers tend to stay loyal if their attitude towards a brand is positive. Contrary to expectations, subjective norms exerted no effect on future intentions in both environmental concern groups. This finding is partly due to Thai consumers' lack of motivation to comply with the views of the others and commitment in conserving the environment. (Lodorfos and Dennis 2008). Extending prior research, the replicated investigation of the relationships between perceived value and future intentions supports the strong value-loyalty relationship in both environmental concern groups. This finding is consistent with previous study of Cronin et al. (2000) and Petrick (2004) who suggested that value is regarded as one of the most powerful prerequisites of loyalty. This study showed strong empirical evidence that tourists holding favorable value were more likely to develop loyalty towards hotels holding environmental concern. Lastly, the significant and positive relationship between destination competitiveness and future intentions is well supported in both groups. Consistent with previous studies (e.g., Crouch and Ritchie, 1999). the finding supports the idea that destination competitiveness contributes to boosting customer loyalty.

\section{MANAGERIAL IMPLICATION}

Based on the findings discussed above, they highlight the importance of consumers' perceived value, attitudes towards the hotel's environmental concern, and destination competitiveness in influencing on service loyalty towards hotels in Koh Samet. First and most important indicator of loyalty, marketing practitioners should concentrate their efforts on developing marketing strategies and programs enhancing customers' perceived value in terms of fair price and good bargain. Secondly, hotel marketers should make a commitment to environmental responsiveness by developing sustainable business initiatives through the consensus of stakeholders. Lastly, tourism 
marketers should incorporate the local authorities in developing the sustainable projects with an aim to conserve and improve the natural resources of Koh Samet.

\section{ACKNOWLEDGMENTS}

The authors wish to thank The Thailand Research Fund for sponsoring this research (Scholarship no. 532011, the research title "Green Hospitality Development Plan of Tourists' Residence in Koh Samet, Rayong Province, Thailand")

\section{AUTHOR INFORMATION}

Jirawat Anuwichanont received his Ph.D. in Marketing Science from Thammasat University, Thailand. He is currently a full-time lecturer of Graduate School, Suan Dusit Rajabhat University, Thailand. He has authored and co-authored academic articles in referred journals and conference proceedings. His research interests include Service Marketing, Tourism Marketing and Brand Management. Correspondence should be addressed to Jirawat Anuwichanont, Suan Dusit Rajabhat University, Room number 1102, Building 1, 295 Rachasima Road, Dusit, Bangkok 10300, Thailand; +66-8-9777-6660; E-mail: jirawata@ hotmail.com.

Assistant Professor Dr. Panisa Mechinda is a full time lecturer at Rajamangala University of Technology Thanyaburi, Thailand. She received Ph.D Degree in Marketing. Her research interest is in the field of service marketing, tourism and branding. Correspondence should be addressed to Panisa Mechinda, Rajamangala University of Technology, Thanyaburi, 39 Rangsit-Nakornnayok Road, Pathumtani 12110 Thailand; +66-8-1844-4660; E-mail: mechinda.panisa@gmail.com

Sirivan Serirat is an associate professor at Suan Dusit Rajabhat University, Thailand. She received the master degree in Economic Development from National Institute of Development Administration, Thailand and the bachelor degree in Commerce from Chulalongkorn University,Thailand. Her research interests revolve around tourism, marketing, management, strategic planning in tourism, SMEs and sustainable tourism in Thailand. Correspondence should be addressed to Sirivan Serirat, Suan Dusit Rajabhat University, Room number 1102, Building 1, 295 Rachasima Road, Dusit, Bangkok 10300, Thailand; +66-8-1335-8777; E-mail: sirivanonline@gmail.com.

Aurathai Lertwannawit, Ph.D. is currently Assistant professor of business administration at the Graduate School of Suan Dusit Rajabhat University. She earned her BBA, major in Marketing from Assumption University and BA in Business Chinese from Beijing Language and Cultural University. Her master's degree is MSc. in Information Technology from Assumption University. And her doctoral degree is Ph.D. in Marketing from Thammasat University. Her research interests include consumer behavior, tourism marketing and management, and relational marketing in business market. Correspondence should be addressed to Aurathai Lertwannawit, Suan Dusit Rajabhat University, Room number 1102, Building 1, 295 Rachasima Road, Dusit, Bangkok 10300, Thailand; +66-8-18750022; E-mail: aurathai@gmail.com.

Nongluck Popichit is a full-time lecturer in faculty of Management Science at Suan Dusit Rajabhat University, Thailand. She received the master degree in Management from Srinakharinwirot University, Thailand. Her research interests revolve around tourism, management, marketing, and sustainable tourism in Thailand. Correspondence should be addressed to Aurathai Lertwannawit, Suan Dusit Rajabhat University, Room number 1102, Building 1, 295 Rachasima Road, Dusit, Bangkok 10300, Thailand; +66-8-9927-3522; E-mail: npopichit@gmail.com

\section{REFERENCES}

1. Ajzen, I. 1991, 'The Theory of Planned Behavior', Organizational Behavior and Human Decision Processes, vol. 50, pp.179-211. Doi:10. 1016/0749-5978(91)90020-T.

2. Ajzen, I., and Fishbein, M. 1970, 'The Prediction of Behavior from Attitudinal and Normative Beliefs', Journal of Personality and Social Psychology, vol. 6, pp. 466-487. 
3. Ajzen, I., and Fishbein, M. 1980, 'Understanding Attitudes and Predicting Social Behavior, Prentice-Hall, Englewood Cliffs', $\mathrm{Nj}, 1980$.

4. Bolton. 1991, 'A Multistage Model of Consumers Assessments of Service Quality and Value', Journal of Consumer Research, vol.17, no. 4, pp. 95-108.

5. Bolton, R. N. and Drew, J. H. 1991, ‘A Multistage Model of Customers' Assessments of Service Quality and Value', Journal of Consumer Research, vol. 17 (March), pp.275-84.

6. Bonifant, B., Arnold, M.B., \& Long, F.J. 1995, 'Gaining competitive advantage through environmental investments', Journal of Business Horizons, pp. 37-47.

7. Boulding, William, Ajay Kalra, Richard Staelin, and Valarie A. Zeithaml. 1993, 'A Dynamic Process Model of Service Quality: From Expectations to Behavioral Intentions,' Journal of Marketing Research, vol. 30, pp. 7-27.

8. Bowen, J.T. and S. Shoemaker. 1998, 'Loyalty: A Strategic Commitment,' Cornell Hotel and Restaurant Administration Quarterly, vol. 39, no. 1, pp. 12-25.

9. Chan, T. S. 1996, 'Concerns for Environmental Issues and Consumer Purchase Preferences; A TwoCountry study,' Journal of International Consumer Marketing, vol. 9, pp. 43-55.

10. Chaudhuri, A.and M.Holbrook . 2001, 'The Chain of Effects from Brand Trust and Brand Affect to Brand Performance: The Role of Brand Loyalty,' Journal of Marketing, vol. 65, pp. 81-93

11. Cronin, J. J., Brady, M. K. \& Hult, G. T. M. 2000, 'Assessing the Effects of Quality, Value and Customer Satisfaction on Consumer Behavioral Intention in Service Environments', Journal of Retailing, vol. 76 (2), pp.193-218.

12. Crouch, G. I., \& Ritchie, J.R.B. 1999, 'Tourism, competitiveness, and social prosperity,' Journal of Business Research, vol. 44, pp. 137-152.

13. Dunn, R., \& Iso-Ahala, S. 1991, 'Sightseeing tourists' motivations and satisfaction', Annals of Tourism Research, vol. 18 no. 2, pp. 226-237.

14. Dwyer, F.R., Schurr, PH., \& Oh, S. 1987, 'Developing buyer-seller relationship', Journal of Marketing, vol. 51, no. 2, pp. 11-27.

15. Dwyer, L., Livaic, Z., \& Mellor, R. 2003, 'Competitiveness of Australia as a tourist destination', Journal of Hospitality and Tourism Management, vol. 10, no. 1, pp. 60-78.

16. Emre V. Ozdemir and Hewett Kelly. 2010, 'The Effect of Collectivism on the Importance of Relationship Quality and Service Quality for Behavioral Intentions: A Cross-National and Cross-Contextual Analysis', Journal of International Marketing, vol. 18, no. 1, pp. 41-62.

17. Fishbein, M., \& Ajzen, I. 1975, 'Belief, Attitude, Intention and Behavior: An Introduction on Theory and Research', Reading, MA: Addison-Wesley.

18. Fitzmaurice, J. (2005). 'Incorporating Consumers' Motivations Into the Theory of Reasoned action', Psychology and Marketing, vol. 22, no. 11, pp. 911-929.

19. Hellier, P.K., G. Geursen, R.A. Carr, and J. A. Reichard. 2003, 'Customer Repurchase intention: A General Structural Equation Model', Europe Journal of Marketing, vol. 37, no. 11/12, pp. 1762-1800.

20. Hines. Jody M., Herald R. Hungerford, and Audrey N. Tomera. 1987, 'Analysis and Synthesis of Research on Research on Responsible Environmental Behavior: A Meta-Analysis,' Journal of Environmental Education, vol. 18, pp. 1-8.

21. Hübner, G., \& Kaiser, F. G. 2006, The Moderating Role of the Attitude-Subjective Norms conflict on the link between moral norms and intention. European Psychologist, vol. 11, no. 2, pp. 99-109.

22. Kirk, D. and Macdonald, D. (1998) 'Situated Learning in Physical Education', Journal of Teaching in Physical Education vol. 17, no. 3, pp. 376-387

23. Legris, Paul, John Ingham, and Pierre Collerette. 2003, 'Why Do People Use Information Technology? A Critical Review of the Technology Acceptance Model', Information \& Management, vol. 40, no. 3, pp. 191-204.

24. Mathieson A \& Wall G. 1982, Tourism: economic, physical and social impacts, Longman, Harlow, UK.

25. Miles, M.P., \& Covin, J.G. 2000, 'Environmental marketing: a source of reputation, competitive, and financial advantage', Journal of Business Ethics, vol. 23, no. 3, pp. 299-311.

26. Milfont., \& Duckitt, J. 2004, 'The Structure of Environmental Attitudes: a First-and Second-Order Confirmatory Factor Analysis', Journal of Environment Psychology, vol. 24, pp. 289-303. 
27. Ming-Shen Wang, Chin-Chung Chen, Su-Chao Chang and Yung-Her Yang. 2007, 'Effects of Online Shopping Attitudes, Subjective Norms and Control Beliefs on Online Shopping Intention: A Test of the Theory of Planned Behaviour', International Journal of Management, vol. 24 no. 2, pp. 296-302

28. Oliver, R.L. \& Desarbo, W.S. 1988, 'Response Determinants in Satisfaction Judgments,' Journal of Consumer Research, vol.14, pp. 495-507.

29. Parasuraman, A., Leonard L. Berry, and Valarie A. Zeithaml. 1991, 'Refinement and Reassessment of the SERVQUAL Scale', Journal of Marketing, vol. 67, no. 4, pp. 420-50.

30. Parasuraman, A. 1997, 'Reflections on Gaining Competitive Advantage through Customer Value', Journal of the Academy of Marketing Science, vol. 25 (2), pp.154-64.

31. Pavlou, P.A., \& Fygenson, M. 2006. 'Understanding and Predicting electronic commerce adoption: An Extension of The Theory of Planned Behavior', MIS Quarterly, vol. 30, no. 1, pp. 115-143.

32. Petrick, F. 2004, 'First Timers and Repeaters Perceived Value,' Journal of Travel Research, vol. 43, pp. 29-38.

33. Petrick, J. F., Morais, D. D. and Norman, W. C. 2001, 'An Examination of the Determinants of Entertainment Vacationer' Intentions to Revisit', Journal of Travel Research, vol. 40 (August), pp.41-48.

34. Reichheld, F.F. and Sasser, W.E. 1990, 'Zero Defections: Quality Comes to Services', Harvard Business Review, vol. 68, no. 5, pp. 105-111.

35. Rust, R.T., Zeithaml, V.A., and Lemon, K.A. (2000), 'Driving Customer Equity', The Free Press, New York, NY.

36. Simmons, Deborath and Ron Widmar. 1990, 'Motivations and Barriers to Recycling: Toward a Strategy for Public Education,' Journal of Environment Education, vol. 22, pp. 13-18.

37. Suzanne Bergin-Seers and Judith Mair. 2009, 'Emerging green tourists in Australia: Their behaviours and a attitudes', Tourism and Hospitality Research, Vol. 9, no. 2, pp. 109-119.

38. Thorbjornsen, H., Pedersen, P.E., \& Nysveen, H. 2007. 'This is Who I am': Identity Expressiveness and the Theory of Planned Behavior', Psychology and Marketing, vol. 24, no. 9, pp. 763-785.

39. Woodruff, R. B. 1997, 'Customer Value: the Next Source for Competitive Advantage', Journal of the Academy of Marketing Science, vol. 25 (2), pp.139-53.

40. Yeonshin Kim, Sejung Marina Choi. 2005, 'Antecdent of Purchase Behavior: An Examination of Collectivism, Environmental Concern, and PCE', Advance in consumer Research, vol. 32, pp. 592-599.

41. Zeithaml, V. A. 1988, 'Consumer Perceptions of Price, Quality and Value: A Means-End Model and Synthesis of Evidence', Journal of Marketing, vol. 52 (July), pp.2-22.

42. Zeithaml, Valarie, Leonard Berry, and A. Parasuraman. 1996, 'The Behavioral Consequences of Service Quality,' Journal of Marketing, vol. 60, no. 2, pp. 31-46. 